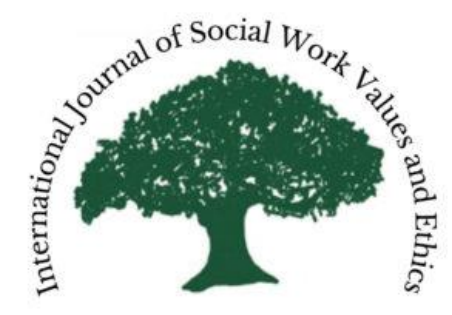

International Journal of Social Work Values and Ethics

Volume 19, Number 1 (2022)

ISSN: 2790-6345

DOl: 10.55521/10-019-100

www.jswve.org 


\section{The Importance of Social Work Ethics and Values at a Time of Global Change}

DOl: 10.55521/10-019-102

Rory Truell, Ph.D.

\section{International Journal of Social Work Values and Ethics • Volume 19(1), Copyright 2022 by IFSW}

This text may be freely shared among individuals, but it may not be republished in any medium without express written consent from the authors and advance notification of IFSW.

Social work ethical principles have taken centre stage reaching multiple organisations that represent 100 s of millions of people. The people's global summit that takes place in June / July this year is a ground-up process initiated by social work to develop a new agenda for an eco-social world that leaves no on behind. The many global partners that have committed to this process have embraced the social work values of holistic rights, human dignity, the right to self-determination, recognising/celebrating diversity and building solidarity.

These, now shared values, are inspiring widespread contributions on what direction the world needs to take as we emerge out of the pandemic. People from communities, governments, civil society organisation, professions as well as UN agencies are championing new policy ideas that effect every facet of life. Here is an example of some of some of the headline themes from social work that will be considered in the summit:

- Economics: From market driven economies to sustainable well being societies

- Environment: From exploitation to recognizing the rights of nature for sustainable co-existence

- Nationalism: From national introspection to global citizenship

- Business: From independent markets to sustainable cooperation 
- Work: From being undervalued to recognition and decent working conditions.

- State responsibility: From reactive public spending to public investment in wellbeing

The International Federation of Social Workers invites all readers of this journal to become actively involved in the summit discussions. The social work profession's grounded experience and insights into what values and policies enable people to sustainably thrive and what values and policies undermine them is critical information as we work towards co-shaping new agendas. As some of the non-social work partners in the summit have noted, 'social work was key in developing the New Deal following the great depression and social work was a significant force in the development of the International Declaration of Human Rights following the second world war'. At this moment in history with climate change, the failing global economy, increased military actions and a worldwide pandemic, it is again time for the profession to promote change based on our longstanding and tested ethics and values. 